\title{
19 Unleashing the power of vegetables and fruits in Southern Africa
}

\author{
Thomas Dubois, Thibault Nordey \\ and Umezuruike Linus Opara
}

\section{Vegetables and fruits for nutrition and income generation}

Vegetables and fruits are a vitally important source of micronutrients, vitamins and minerals and therefore essential components of balanced and healthy diets. Yet, production and demand are still too low to provide the population in many countries in Southern Africa with the minimum per capita consumption of $400 \mathrm{~g} /$ person/day required for good health (FAO/WHO, 2004). In Africa, most countries do not reach even half of this minimum requirement (AmbroseOji, 2009). Of particular importance are traditional African vegetables such as amaranth, African eggplant, roselle, okra and many others that have been cultivated in African gardens for decades. These "superfoods" provide much higher amounts of provitamin A, vitamin C and several important minerals than staples and globally traded vegetables (WorldVeg, 2018). They also contain antioxidants and other health-related phytochemicals that prevent chronic diseases such as cancer and cardiovascular disease. For growers, vegetables and fruits are often more profitable per unit volume than staples and command higher profit margins and farm gate prices per unit area of production, especially when access to farmland is limited and labour is surplus (Gabre-Madhin and Hagglade, 2003), like in many rural parts of Southern Africa. As such, vegetables and fruits are great income generators and profit can be achieved on relatively small land units. Nevertheless, sustainable and market-oriented production and consumption of safe vegetables and fruits is not being achieved in many parts of Africa, including Southern Africa. The predominant staple-based diets in the region, based on maize, wheat and rice need to be diversified with vegetables and fruits to increase nutrition and income.

\section{Key drivers for horticulture in Southern Africa: constraints and opportunities}

\section{Climatic conditions}

Climatic conditions (temperature and solar radiation) in Southern Africa are suitable for year-round production of vegetables and tropical fruits (such as 
mango, banana, citrus and avocado) and temperate fruits (such as apple, pear and grape) at higher elevations. The main limiting factors, however, are pests, diseases, weeds, low soil fertility and lack of year-round water supply. These constraints are exacerbated by the effects of climate change. Whereas temperatures and carbon dioxide will gradually increase, more worry that rainfall will become more erratic with increased incidence of floods and droughts. A major effect is likely increases in pest and disease pressures.

\section{Urbanization and the supermarket revolution}

Africa is experiencing the world's most rapid rate of urbanization at $\sim 3.5 \%$ per year, with over $40 \%$ of its population already living in cities. In the near future, food demand in Africa will come from urban populations, and agricultural systems, including horticulture, will need to become more efficient, with lower transaction costs and increased capital per worker, facilitating a sharp increase in the use of purchased inputs and specialized capital provided by local agribusinesses (Masters et al., 2013). Production will be concentrated in or around urban areas. Because of their short value chains, scale neutrality and high profitability on small plots of land, horticulture is well positioned to become a key driver of future African agriculture, which is set to shift towards urban and peri-urban systems.

Consumption habits are expected to change with urbanization. Consumers in Southern Africa will increasingly demand uniformity, packaging and convenience offered by formal retail outlets as opposed to traditional markets, triggering a supermarket revolution as seen recently in Asia and Latin America. By 2004, South Africa had almost 2,000 large supermarkets, from very few during the Apartheid era, and Lusaka, Zambia, has more than 100 large supermarkets, from virtually none three decades earlier (Reardon et al., 2004). It is hoped that this transformation in Southern Africa will improve market institutions, break monopolies, improve farmers' terms of trade and create a competitive market for inputs and farm credit, as has happened during Asia's supermarket revolution (Reardon, 2013).

\section{Postharvest}

Postharvest losses of horticultural produce in Southern Africa are staggering, e.g., 55\% for mangoes, $43 \%$ for leafy vegetables and 33\% for tomatoes (Affognon et al., 2015), and as such, the lack of suitable postharvest handling and processing is likely among the key constraints for horticulture in sub-Saharan Africa. Short shelf-life is a major hurdle, especially for vegetables. High-value perishable products such as vegetables and fruits are presently almost exclusively supplied by urban and peri-urban farmers because of resulting short value chains (Chagomoka et al., 2016).

Cold chain technologies and infrastructure remain the holy grail for fresh horticultural value chains in Southern Africa. An alternative to the need of 


\section{Thomas Dubois et al.}

cold chains is value addition through processing, including pickling, drying and sauce and jam making. Numerous preharvest and postharvest technologies are developed for smallholder farmers, including improved varieties that have longer shelf-life or can withstand transport better; technologies related to field handling and harvesting procedures to reduce damage; sanitizing pretreatments such as the use of calcinated calcium; and modified atmospheric packaging. Although these technologies generally work well under local conditions and would be easily adoptable by smallholder horticulturalists, they are difficult to pull into the market due to several factors, including lack of finance and technical know-how. Even the simplest of postharvest technologies, such as sorting and grading, can increase market value by $20-60 \%$, merely by segregating produce by size or applying ethylene on climacteric fruit to control ripening. Yet few smallholder farmers engage in these improved postharvest quality management activities and therefore are limited in their access to regional and international markets.

\section{Dichotomy between local low-input and regional high-input production}

In Southern Africa, smallholder cultivation of fruits and vegetables for home and local market consumption differs significantly from medium- and large-scale business-oriented production. Each system has different investment capacity and requires different production technologies, especially for vegetables where greenhouses may be needed. Only more intensive and profitable production systems can ensure compliance with regulations on maximum pesticides residue levels and target export market standards. Although most horticultural products are still sold in local markets, exports from Southern Africa have increased more than 2.5-fold between 2006 and 2016 (FAO, 2017). Whereas regional exports are much more important than exports to Europe, Asia and the U.S., exports to the latter areas will develop further under the economic partnership agreement signed between the EU and six SADC members (Bertelsmann-Scott and Markowitz, 2018).

\section{Food safety}

A major barrier to vegetable and fruit production is access to sufficient, yearround supply of clean water for quality irrigation and postharvest cleaning. Use of unclean water, such as wastewater in urban areas or water used in wet markets, poses serious health risks due to microbial contamination, especially for fresh produce such as green leafy vegetables. A microbial risk assessment in Ghana's major cities estimated a possible loss of about 12,000 disability-adjusted life years annually resulting from the consumption of wastewater-irrigated lettuce alone (Drechsel and Seidu, 2011). In addition, green leafy vegetables accumulate heavy metals present in industrially contaminated water in high concentrations (Arora et al., 2008) to the potential detriment of human and livestock health.

Consumer health is further compromised by excessive and erroneous use of pesticides. Their application is relatively cheap for high-value horticulture 
crops, and they are seldom applied according to label specifications (proper dose, active ingredient, timing, mixture, application method and/or safety equipment) (Dinham, 2003). Runoff causes contamination of soil and especially groundwater, further compromising the water supply. Farmers do not have proper access to training in chemical use from extension services.

\section{Technologies that can be implemented}

\section{Moving from technological to institutional and organizational interventions}

Numerous efficient technologies are available for smallholder horticulturalists (i.e., irrigation systems, fertilization, improved varieties, integrated pest management, protected cultivation). However, enticing adoption of these technologies is difficult, partly due to the high input requirements and complexity of horticultural value chains as explained previously. It is important that technological innovations are embedded in institutional (laws, regulations and standards but also soft assets such as social and cultural norms) and organizational contexts and innovations.

One example is implementing postharvest-related technologies at scale. Postharvest is a complex problem, especially for smallholder farmers, and complex problems need innovative solutions. Most researchers, when focusing on developing, testing and validating new postharvest technologies, focus on the technological aspects for smallholder farmers, yielding new products and processes. However, actors, especially in complex systems such as postharvest systems for smallholders in Africa, are not isolated and never act alone. For postharvest technology to work, the technological, institutional and organizational aspects are equally important. Many functions along the value chain, including processing, packaging, wholesaling and retailing, are becoming separated in space and time, with different facilities and infrastructure where these functions take place. In Africa, most vegetable and fruit farmers are small-scale, often women, with little access to inputs, finance, information and markets. Aggregation of these many informal or semi-formal growers is an essential organizational innovation that remains a huge challenge.

Another example is the supermarket revolution that Southern Africa is currently experiencing. These supermarkets are leading the way in overhauling the traditional procurement model of sourcing products from the traditional wholesalers and wet markets. The supermarket chains seek constantly to lower product and transaction costs and risk - with the result of selecting only the most capable farmers, and in many African countries these are mainly the medium and large farmers. Moreover, as supermarkets compete with each other and with the informal sector, they will not allow consumer prices to increase, and ultimately horticultural farmers cannot avoid paying for costs such as safe water and record keeping systems. This will be a huge challenge for small operators and consequently, retail concentration will cascade into supplier concentration (Reardon et al., 2004; Reardon, 2013). 


\section{Seed and seed systems}

A major bottleneck is lack of selection and breeding research related to vegetables and fruits that are adapted for Southern Africa, and this is especially the case for traditional African vegetables (Dinssa et al., 2016). Efforts related to selection and breeding need to be coupled with effective seed supply systems, proper agronomic practices and an adequate regulatory and policy framework, supported by a growing private seed supply sector.

The horticultural seed sector in Southern Africa is not as regulated nor effective as that of staple crops. Few companies are present that have active breeding and seed dissemination programmes targeting smallholder farmers (Access to Seed Foundation, 2016). Also, seed companies do not have good geographic penetration and only serve directly the large metropolitan areas. In addition, low quality and even counterfeit seeds flood local markets.

The seed sector needs to function using a value chain approach and ensure strategic linkages of seed producers to key value chain actors such as extension (for technical advice), regulation (for seed inspection and certification), research (for provision of varieties and foundation seed), market (as seed/off-takers) and credit service providers. Only when driven by market forces will seed production and marketing be sustainable. Governments still play a crucial role in helping this transition, for example, through introduction of quality declared seed systems into national regulations.

\section{Needed policies and their processes for implementation}

\section{Increasing consumer demand for vegetables and fruits}

Many towns and cities in sub-Saharan Africa are characterized by unsustainable consumption patterns. They are undergoing a nutritional transformation away from traditional diets to increased consumption of dairy products and meat, less complex carbohydrates and a general decline in dietary diversity and nutritional value (Ambrose-Oji, 2009). Such unsustainable consumption patterns are especially worrying among children, as dietary patterns are well established by the age of 13, and dietary patterns that develop in childhood often are maintained into adulthood (Nicklas, 1995). Governments are pivotal in reversing this worrisome decline and should actively stimulate demand for locally produced vegetables and fruits. Of particular focus are children, for whom the importance of fruit and vegetable consumption should be included in school curricula.

\section{Quality standards through voluntary labels}

Food safety is of high concern in horticultural products. However, in Southern Africa, there are few standards such as those related to maximum residue limits, and if these standards are present, they are mostly not implemented or adhered to, except for export overseas. However, large outlets in sub-Saharan Africa, 
such as international supermarkets, are starting to pay attention to maximum residue limits and traceability. Together with the move to more global crops, this may force them to import vegetables and fruits for African markets from more advanced economies, at the detriment of local farmers. This scenario is already happening in the large cities within Kenya, Mozambique and Tanzania (Dinham, 2003). To implement good agricultural practices and remain within maximum residue limits, policy regulatory frameworks need to be in place and enforced by officials. At present, lack of human, infrastructure and financial capacity will likely not make this possible in the near future in many countries in Southern Africa.

More important, the driver for ensuring safely produced vegetables and other horticultural products needs to come from the demand side - consumers. However, unlike in developed countries, consumers in sub-Saharan Africa do not yet demand or are not willing to pay a premium for safely produced food. Through Southern Africa's nascent supermarket revolution, transformation from local, low-value and unbranded foods to branded, high-value and sometimes processed goods is set to happen. It is important that smallholders reap the benefits of this revolution. A solution is to slowly and stepwise implement private safety standards for horticultural products and selling these to increasingly food safety-aware consumers using local, voluntary labels (e.g., by the Common Market for Eastern and Southern Africa Comprehensive African Agriculture Development Programme for its member countries).

\section{Improving market access through farmer aggregation, with a focus on youth and women}

Horticultural producers usually sell their products to village collectors or petty traders at low farm-gate prices. Producer groups exist but are too small to negotiate prices with traders or processors directly and only serve as collection centres for larger traders or processors. Also, limited or no access to formal sources of finance creates an impediment to vegetable and fruit production for youth and women because they have insufficient or no collateral. Commercial banks, due to high transaction costs associated with credit monitoring and production risks of individual smallholders or informal groups, may be reluctant to provide credit or invest. Finally, governmental extension systems are often poorly skilled in other than staple crop systems, are geared towards men and have little or no access to new technologies and practices that are relevant for smallholder horticulture farmers.

Women and youth are especially disadvantaged in relation to market access. Women are the custodians of local horticultural value chains in Southern Africa, functioning as the gatekeepers of the nutritional benefits of vegetables and fruits for local communities, while youth are attracted to their income-earning potential. As such, women and youth have a huge potential to contribute to and benefit from horticulture, yet there are multiple reasons why this potential is not being realized. A primary reason is lack of skills and knowledge, which 
are in general more elevated than those of other crops and for which youth and women are at a disadvantage compared to men, often resulting in adhering to suboptimal and subsistence-based agricultural practices. Youth and women also lack access to high quality inputs such as improved seeds and fertilizers. Provided capital is available, the majority of smallholder horticultural producers buy their inputs and technologies from local agro-dealers. The quality of these inputs, particularly seeds and fertilizers, is often very poor, and accreditation through governmental bodies is in most countries absent or not enforced.

\section{Beyond staples: a shift in agricultural research towards horticulture}

Although agriculture is currently deemed an essential driver for development in sub-Saharan Africa, research on horticulture is treated as secondary to that of staple crops, despite the nutritional and income-generating potential of vegetables and fruits. For instance, large African bodies setting the agricultural research agenda, such as the Alliance for a Green Revolution in Africa, do not include horticulture in their research agendas. Granted, unlike staple crop production, horticulture in Southern and sub-Saharan Africa as a whole is blessed with the attention of a vibrant private sector. However, this private sector is focused on production of mainly global vegetables and fruits and is heavily biased towards overseas export markets. Another reason for lack of investment in horticultural research may be the absence of precise data. Vegetables are largely produced and sold informally, and production, sales and consumption figures are underreported or not documented at all. In FAOSTAT and other databases on which governments and donors rely to make decisions, there is a strong focus on staples, with horticulture largely ignored or grouped together, making it impossible to make valid judgments for any horticultural group, especially local vegetables. Horticultural research requires urgent donor attention and a proactive research agenda, based on disaggregated and reliable production and consumption data. Especially postharvest investments are urgently needed; currently, $<5 \%$ of funding for horticultural research and extension has been allocated to postharvest issues over the past 20 years (Kitinoja et al., 2011).

\section{Focus on traditional African vegetables for regional trade instead of commoditized export crops}

Because of a fast-increasing population and rapid urbanization, natural resources will face increased pressure to produce adequate and nutritious food, and this pressure is further compounded by climate change. Crops are required that can withstand these environmental shocks, increasing resilience of households that grow them. Tomato, cabbage and onion, global commodity vegetables currently grown in Southern Africa as well as French bean and pepper produced for export markets, are relatively sensitive to environmental constraints. On the other hand, traditional African vegetables, which are grown in specific localities 
where they are economically important, may be better suited to thrive under suboptimal and even marginal conditions faced by many vulnerable households. Many of these traditional African vegetables are more resistant to biotic and abiotic stresses (requiring less inputs like fertilizers and pesticides), are easy and fast to grow (allowing for multiple cropping cycles per year on the same plot) and are much more nutritious. Nevertheless, a clear shift exists from traditional to global vegetables in consumption patterns in sub-Saharan Africa (Weinberger and Msuya, 2004). It is important for governments and regional bodies to pay particular attention to these neglected crops.

\section{References}

Access to Seed Foundation (2016) Access to Seeds Index Report 2016. Access to Seed Foundation, Amsterdam.

Affognon, H., Mutungi, C., Sanginga, P. and Borgemeister, C. (2015) 'Unpacking postharvest losses in sub-Saharan Africa: A meta-analysis', World Development, vol 66, pp. 49-68.

Ambrose-Oji, B. (2009) 'Urban food systems and African indigenous vegetables: Defining the spaces and places for African indigenous vegetables in urban and peri-urban agriculture', in, C. M. Shackleton, M. W. Pasquini, and A. W. Drescher (eds) African Indigenous Vegetables in Urban Agriculture. Earthscan, London.

Arora, M., Kiran, B., Rani, S., Rani, A., Kaur, B. and Mittal N. (2008) 'Heavy metal accumulation in vegetables irrigated with water from different sources', Food Chemistry, vol 111, pp. 811-815.

Bertelsmann-Scott, T. and Markowitz, C. (2018) Policy Briefing 174. The Impact of the SADC EPA on South Africa's Agriculture and Agro-Processing Sectors. South African Institute of International Affairs, Johannesburg.

Chagomoka, T., Unger, S., Drescher, A., Glaser R., Marschner, B. and Schlesinger, J. (2016) 'Food coping strategies in northern Ghana. A socio-spatial analysis along the urban - rural continuum', Agriculture and Food Security, vol 5, pp. 1-18.

Dinham, B. (2003) 'Growing vegetables in developing countries for local urban populations and export markets: Problems confronting small-scale producers', Pest Management Science, vol 59, pp. 575-582.

Dinssa, F. F., Hanson, P., Dubois, T., Tenkouano, A., Stoilova, S., Hughes, J. D. A. and Keatinge, J. D. H. (2016) 'AVRDC - The World Vegetable Center's women-oriented improvement and development strategy for traditional African vegetables in sub-Saharan Africa', European Journal of Horticultural Science, vol 81, pp. 91-105.

Drechsel, P. and Seidu, R. (2011) 'Cost-effectiveness of options for reducing health risks in areas where food crops are irrigated with treated or untreated wastewater', Water International, vol 36, pp. 535-548.

FAO (2017) FAOSTAT. FAO, Rome.

FAO/WHO (2004) Fruits and Vegetables for Health. FAO, Rome.

Gabre-Madhin, E. Z. and Hagglade, S. (2003) Successes in African Agriculture: Results of an Expert Survey. Markets and Structural Studies Division Discussion Paper No. 53. IFPRI, Washington, DC.

Kitinoja, L., Susanta, S. S. and Kader, A. A. (2011) 'Postharvest technology for developing countries: challenges and opportunities in research, outreach and advocacy', Journal of the Science of Food and Agriculture, vol 91, pp. 597-603. 
Masters, W. A., Djurfeldt, A. A., De Haan, C., Hazell, P., Jayne, T., Jirström, M. and Reardon, T. (2013) 'Urbanization and farm size in Asia and Africa: implications for food security and agricultural research', Global Food Security, vol 2, pp. 156-165.

Nicklas, T. A. (1995) 'Dietary studies of children: the Bogalusa heart study experience', Journal of the Academy of Nutrition and Dietetics, vol 95, pp. 1127-1133.

Reardon, T. (2013) The Economics of Urbanization, Farm Technology, and Farm Size Distribution in Asia. CGIAR, Montpellier.

Reardon, T., Timmer, P. and Julio Berdegue, J. (2004) 'The rapid rise of supermarkets in developing countries: Induced organizational, institutional, and technological change in agrifood systems', Electronic Journal of Agricultural and Development Economics, vol 1, pp. 168-183.

Weinberger, K. and Msuya, J. (2004) Indigenous Vegetables in Tanzania: Significance and Prospects. WorldVeg, Shanhua.

WorldVeg (2018) Annual Report 2017. WorldVeg, Shanhua. 